\title{
ANALISIS PERLAKUAN AKUNTANSI ASET BIOLOGIS PADA PERUSAHAAN SEKTOR AGRIKULTUR SUBSEKTOR PERKEBUNAN YANG TERDAFTAR DI BURSA EFEK INDONESIA (BEI)
}

\author{
Retno Wulandari ${ }^{1}$ \\ Fitri Laela Wijayati, SE., M.Si. ${ }^{2}$ \\ *Akuntansi Syariah, Fakultas Ekonomi dan Bisnis Islam \\ *Dosen Akuntansi Syariah, Fakultas Ekonomi dan Bisnis Islam \\ wretno66@yahoo.co.id \\ fitriwijayati@gmail.com
}

\begin{abstract}
This paper aims to analyze how the accounting treatment for biological assets in agricultural companies subsectors listed in the Indonesia Stock Exchange.

This paper is a cualitative study with descriptive analyse. The study data used secondary data in annual report of sample companies in 2016. The sample 14 companies with sampling technique using purposive sampling.

The results show that biological assets are divided into two types of annual crops and seasonal crops. The accounting treatment of biological assets is based on PSAK No. 16- fixed assets and PSAK No. 14 inventories. Based on the comparison of biological asset accounting treatment in companieshas accordance with accounting standards used.
\end{abstract}

Keywords: Accounting treatment, agricultural company, biological asset, PSAK 14, PSAK 16.

1.

PENDAHULUAN

Sumber daya alam berlimpah berdampak pada beragamnya komoditas alam atau agrikultur. Produk agrikultur berperan penting dalam perekonomian Indonesia karena sektor agrikultur menjadi sektor kedua yang berpengaruh dalam pertumbuhan ekonomi Indonesia setelah sektor industri pengolahan berdasarkan struktur produk domestik bruto. Triwulan II-2017 sektor agrikultur berkontribusi sebesar 13,92\% dan pada triwulan III-2017 berkontribusi sebesar 13,96\% dilihat dari Struktur PDB (Produk Domestik Bruto) Menurut Lapangan Usaha Atas Dasar Harga Berlaku (Badan Pusat Statistik, 2017). Sektor agrikultur adalah sektor yang bergerak dalam bidang tanah atau pertanian dan terbagi menjadi beberapa sub sektor yaitu perkebunan, holtikultura, kehutanan, florikultura, perikanan, dan peternakan (Trina, 2017). Perusahaan agrikultur khususnya di bidang perkebunan kini semakin meningkat dari segi kuantitas dibuktikan dengan semakin luasnya lahan yang berdampak pada produksi produk/komoditas perkebunan yang semakin meningkat (Badan Pusat Statistik, 2017).

Perusahaan agrikultur memiliki aset yang berkarakteristik unik yang membedakan dengan aset dari perusahaan sektor lain yaitu aset biologis (hewan dan tumbuhan) (Putri, 2014). Aset tersebut dinamakan sebagai aset biologis karena aset mengalami transformasi biologis (Utomo dan Khumaidah, 2014). Transformasi biologis berupa proses pertumbuhan, degenerasi, produksi, dan prokreasi. Transformasi biologis memungkinkan informasi yang disajikan oleh perusahaan agrikultur lebih bias daripada perusahaan di bidang lain karena nilai sebenarnya dari suatu aset cenderung berubah seiring dengan adanya transformasi biologis tersebut sehingga aset biologis perlu pengukuran khusus yang dapat menunjukkan nilai wajar aset tersebut sesuai dengan kontribusinya dalam menghasilkan aliran keuntungan ekonomis pada perusahaan (Eltanto, 2014).

International Accounting Standard (IAS) 41 mengatur secara khusus mengenai pengakuan, pengukuran, penyajian, dan pengungkapan terkait aset biologis atau aktivitas pada perusahaan agrikultur (Farida, 2014). IAS 41 mengakui aset biologis pada pengakuan awal dan pada setiap tanggal neraca, diukur berdasarkan nilai wajar (Putri, 2012). Perlakuan aset biologis menggunakan konsep nilai wajar dianggap mampu meningkatkan karakteristik kualitatif dapat diperbandingkan dalam laporan keuangan entitas (Liliana, et.al., 2012).

Praktiknya, perlakuan aset biologis di Romania sebagian besar perusahaan agrikultur menerapkan peraturan Minister of Public Finances' Decree 
3055/2009. Aset biologis dalam pelaporan keuangan terlihat dalam aset lancar dan aset tidak lancar. (Liliana, et.al., 2012), perusahaan agrikultur di Malaysia melaporkan aset biologis berdasarkan pada Malaysian Accounting Standard Board (MASB). Pelaporan keuangan dan pengukuran aset biologis sesuai dengan MAS 8 - Accounting for Pre-cropping costs. MAS 8 mengidentifikasi dua metode akuntansi dan pelaporan aset biologis yaitu, amortisation method untuk perlakuan Pre-cropping costs dan capital maintenance method sebagai perlakuan alternatif (Muhammad dan Ghani, 2014).

Praktik perlakuan akuntansi aset biologis di Indonesia berdasarkan pada Pernyataan Standar Akuntansi Keuangan (PSAK) Nomor 16 mengenai Aset Tetap dan PSAK Nomor 14 mengenai Persediaan (Yani dkk, 2017). Aset biologis memiliki karakteristik yang hampir sama dengan aset tetap, bedanya aset biologis adalah aset berupa benda hidup yang dari waktu ke waktu mengalami perubahan biologis sehingga sebelum ada standar khusus perlakuan aset biologis mengacu pada PSAK 16. Hasil dari aset biologis biasa disebut sebagai produk agrikultural. Perlakuan produk agrikultural mengacu pada PSAK 14 mengenai persediaan.

Penelitian Eltanto (2014) dan Simanjorang dan Supatmi (2014) menyatakan bahwa pada PT X dan PTPN di Indonesia mengakui dan mengukur aset biologis yang dimiliki berdasarkan PSAK 16 di mana didasarkan pada harga perolehan dan PSAK 14 mengenai Persediaan. Penelitian Korompis (2016), Farida (2014), Murtianingsih dan Setiawan (2016) menyatakan petani Likupan, PTPN VII, dan PT Milkindo, Tbk mengukur aset biologis dengan harga perolehan, nilai wajar tidak dapat diterapkan dalam semua jenis aset biologis Murtianingsih dan Setiawan (2016). Penelitian Sari (2014) dan Adita dan Kiswara (2012) membandingkan perlakuan akuntansi aset biologis perusahaan dengan Standar Akuntansi Keuangan (SAK) menunjukkan bahwa tidak ada perbedaan signifikan perlakuan akuntansi perusahaan dengna SAK. Namun, penilaian dengan nilai wajar berdasarkan IAS 41 lebih relevan ditentukan ketika nilai wajar dapat ditentukan secara andal, jika tidak dapat ditentukan dengan andal nilai wajar dapat ditentukan berdasarkan pengelompokkan usia dan kualitas aset biologis.

Penelitian ini dilakukan pada perusahaan agrikultur subsektor perkebunan. Penelitian ini dimaksudkan untuk dapat mengetahui bagaimana perlakuan akuntansi aset biologis pada perusahaan agrikultur subsektor perkebunan yang Terdaftar di Bursa Efek Indonesia (BEI), standar akuntansi yang digunakan, dan mengetahui kesesuain perlakuan akuntansi dengan standar yang digunakan.

\section{KAJIAN PUSTAKA}

\section{Teori Entitas}

Teori entitas memandang bahwa entitas terpisah dengan pemilik (Harahap, 2011:12). Entitas sebagai unit bisnis bertanggungjawab terhadap kepentingan pemilik maupun kreditor. Unit bisnis memiliki sumber daya dan menjadi pusat kepentingan akuntansi. Aset merupakan hak perusahaan dan utang serta ekuitas adalah sumber aset yang digunakan untuk mendanai perusahaan. Teori ini disebut sebagai pusat pendapatan (income) sehingga teori ini berpusat pada laporan laba rugi. Pertanggungjawaban kepada pemilik dilakukan dengan cara mengukur prestasi keuangan yang ditunjukkan perusahaan (Suwardjono, 2014:217).

Teori entitas bersangkutan pada penelitian ini karena perusahaan sebagai entitas, berdiri menjadi suatu unit bisnis yang terpisah dengan pemilik. Pemilik dalam hal ini adalah kreditor dan investor atau pemegang saham, unit bisnis memiliki sumber daya yang diperoleh dari pemilik sehingga entitas atau unit bisnis bertanggungjawab atas sumber daya tersebut (Riahi dan Belkaoui, 2007:275). Bentuk tanggungjawab dapat dilakukan dengan melakukan pengelolaan keuangan yang baik sehingga memberikan informasi yang tepat dan relevan.

\section{Pengungkapan}

Pengungkapan secara teknis didefinisikan sebagai langkah akhir dalam proses akuntansi yaitu penyajian informasi dalam bentuk seperangkat penuh statemen keuangan. Secara umum, pengungkapan merupakan konsep, motode, dan media tentang bagaimana informasi akuntansi disampaikan kepada pihak yang berkepentingan (Suwardjono, 2014:578). Riahi dan Belkaoui (2007:275) menyebutkan bahwa tujuan pengungkapan adalah menguraikan hal yang diakui dan memberikan pengukuran yang relevan, menguraikan hal yang diakui dan memberikan pengukuran yang bermanfaat bagi hal tersebut, memberikan informasi yang dapan membantu investor dan kreditor menilai risiko dan potensial dari hal yang diakui dan tidak diakui, memberikan informasi penting yang memungkinkan pengguna informasi dapat 
melakukan perbandingan, informasi mengenai arus kas masuk atau keluar di masa depan, dan membantu investor menilai pengembalian dari investasi mereka.

Metoda pengungkapan berkaitan dengan masalah bagaimana informasi disajikan melalui pelaporan keuangan. Informasi yang dapat disajikan dalam pelaporan keuangan dapat berupa pos statemen keuangan, catatan kaki, penjelasan dalam kurung, istilah teknis, lampiran, komunikasi manajemen, dan catatan dalam laproan auditor (Suwardjono, 2014:615). Pengungkapan terbagi menjadi dua jenis, pengungkapan wajib dan pengungkapan sukarela. Pengungkapan wajib adalah pengungkapan yang wajib dilakukan perusahaan atau entitas berdasarkan standar akuntansi atau peraturan badan pengawas. Sedangkan, pengungkapan sukarela adalah pengungkapan yang dilakukan perusahaan atau entitas di luar apa yang diwajibkan oleh standar akuntansi atau peraturan badan pengawas (Suwardjono, 2014:583). Penelitian ini lebih berfokus pada pengungkapan wajib yang dilakukan oleh perusahaan, di mana sampai mana perusahaan telah menaati regulasi pengungkapan.

Aset

Pernyataan Standar Akuntansi Keuangan (PSAK) dalam Kerangka Konseptual Pelaporan Keuangan, aset merupakan sumber daya yang dikuasai oleh perusahaan akibat peristiwa masa lalu dan memberikan manfaat di masa depan bagi perusahaan. Suatu objek dapat disebut sebagai aset ketika objek tersebut terdapat tiga karakteristik utama. Karakteristik tersebut yaitu, adanya manfaat ekonomik di masa datang yang cukup pasti, dikuasai atau dikendalikan oleh perusahaan (entitas), dan timbul akibat peristiwa masa lalu (Suwardjono, 2014:254).

Aset disajikan dalam laporan posisi keuangan atau neraca suatu perusahaan. Penyajian aset diurutkan berdasarkan tingkat likuidasi dan kemudahaannya berubah menjadi kas atau berdasarkan masa gunanya (Syakur, 2014:23). Pos-pos yang disajikan dalam laporan posisi keuangan mempertimbangkan penilaian pada siat dan likuiditas aset, fungsi aset, jumlah, sifat, dan jangka waktu. Klasifikasi aset terbagi menjadi lima (Syakur, 2015: 24 dan Baridwan, 2010:20), yaitu aset lancar, investasi jangka panjang, aset tetap berwujud, aset tetap tidak berwujud, aset lain-lain.

\section{Aset Biologis}

Aset biologis dalam IAS 41 diartikan sebagai tanaman dan hewan hidup yang dimiliki oleh perusahaan atau entitas sebagai akibat peristiwa masa lalu dan mampu memberikan manfaat di masa mendatang. Aset biologis mengalami perubahan seiring dengan berjalannya waktu, perubahan tersebut disebut sebagai transformasi biologis. Transformasi biologis IAS 41 paragraf 5 dapat berupa pertumbuhan (bertambahnya kualitas atau peningkatan kuantitas), penurunan kualitas atau kuantitas (degenerasi), menciptakan tumbuhan baru (prokreasi), dan menghasilkan produk (produksi) (Simanjorang dan Supatmi, 2014).

Korompis (2014) mengelompokkan aset biologis berdasarkan masa manfaat menjadi dua jenis, yaitu Aset biologis jangka pendek (Short Term Biological Assets) dimana aset biologis yang memiliki masa manfaat atau masa transformasi kurang dari atau sampai 1 (satu) tahun. Aset biologis berupa tanaman yang jangka waktunya relatif kurang dari 1 tahun adalah tanaman musiman, seperti tebu dan padi. Aset biologis jangka panjang (Long Term Biological Assets) di mana aset biologis yang memiliki masa manfaat atau masa transformasi lebih dari 1 (satu) tahun. Aset biologis berupa tanaman yang jangka waktunya relatif kurang dari 1 tahun adalah tanaman musiman, seperti kopi dan karet.

\section{Standar Akuntansi Perlakuan Aset Biologis.}

\section{IAS 41}

IAS 41 diterbitkan oleh International Accounting Standard Committe (IASC) pada Desember 2000, revisi dilakukan pada tahun 2009. Aset biologis dalam IAS 41 didefinisikan "Biological asset is a living animal or plant". Apabila tanaman atau hewan tersebut dikaitkan dengan aset perusahaan, maka aset biologis merupakan aset yang berupa benda hidup (tanaman ataupun hewan) yang dimiliki perusahaan dengan tujuan untuk mendaparkan keuntungan (Ridwan, 2011 dalam Simanjorang dan Supatmi, 2014)

a. Pengakuan awal

Perusahaan mengakui aset biologis apabila aset tersebut merupakan akibat dari peristiwa masa lalu, memiliki manfaat ekonomik di masa mendatang yang mengalir ke perusahaan, dan nilai wajar atau biaya aset dapat diukur secara andal (IAS 41 paragraf 10 dalam Simanjorang dan Supatmi, 2014). Menurut IAS 41, aset biologis diklasifikasikan menjadi aset dewasa dan aset belum dewasa, serta persediaan berupa produk agrikultur pada titik panen. Aset biologis dalam laporan keuangan diklasifikasikan sebagai aset lancar atau aset tetap berdasarkan jangka waktu transformasi biologis (Eltanto, 2014).

b. Pengukuran 
Pengukuran aset biologis menurut IAS 41 dilakukan pada pengakuan awal dan pada tanggal laporan keuangan didasarkan pada nilai wajar berbasis harga pasar setelah dikurangi dengan taksiran biaya untuk menjual (IAS 41 paragraf 12). IAS 41 memperkenalkan pendekatan nilai wajar (fair value) berbasis harga pasar untuk mengukur aset biologis yaitu aset tanaman dan hewan ternak. IASB juga menyimpulkan bahwa, dalam kasus tertentu, nilai wajar tidak dapat diukur dengan andal (IAS 41 paragraf 19). Sehingga sebagai konsekuensinya diputuskan untuk memasukkan 'pengecualian keandalan' (reliability exception) untuk kasus dimana harga yang ditentukan pasar tidak tersedia, dan alternatif estimasi nilai wajar (alternative estimates of fair value) dinyatakan secara jelas tidak dapat diandalkan (Simanjorang dan Supatmi, 2014).

c. Penyajian dan Pengungkapan

Perusahaan agrikultur dalam IAS 41 Paragraf 4050 (Simanjorang dan Supatmi, 2014) mengungkapkan keuntungan agregat atau kerugian yang timbul selama periode berjalan, deskripsi dari setiap kelompok aset biologis, metode dan asumsi signifikan yang diterapkan dalam menentukan nilai wajar, wajar dikurangi biaya untuk menjual dari produk agrikultural yang telah dipanen selama periode tertentu, keberadaan dan jumlah tercatat dari aset biologis, entitas harus menyajikan daftar rekonsiliasi perubahan dalam nilai tercatat pada aset biologis di antara awal dan akhir periode berjalan.

\section{PSAK 16}

Aset tetap dalam PSAK 16 paragraf 6 adalah aset berwujud yang (a) Dimiliki untuk digunakan dalam produksi atau penyediaan barang atau jasa, untuk direntalkan kepada pihak lain, atau untuk tujuan administratif; dan (b) diharapkan untuk digunakan selama lebih dari satu periode (PSAK 16 paragraf 6).

Syakur (2015:244) menyatakan bahwa aset dapat diklasifikasikan sebagai aset tetap apabila dapat memenuhi empat kriteria memiliki masa manfaat lebih dari satu periode akuntansi, nilainya relatif material, dimiliki untuk tidak dijualm dan digunakan dalam operasi atau kegiatan usaha sehari-hari.

a. Pengakuan

Suatu biaya perolehan aset dikualifikasikan sebagai aset tetap apabila (PSAK 16 paragraf 7):

1) Besar kemungkinan manfaat ekonomis di masa depan berkenaan dengan aset mengalir ke entitas.
2) Biaya perolehan aset dapat diukur dengan andal.

b. Pengukuran

Pengakuan awal aset tetap diukur berdasarkan biaya perolehan (PSAK 16 paragraf 15). Pengukuran berdasarkan biaya perolehan berarti aset tersebut dicatat dan dilaporkan berdasarkan harga atau biaya perolehannya. Biaya perolahan yang dimaksud adalah semua pengorbanan yang dikeluarkan untuk mendapatkan aset sampai aset siap untuk digunakan (Harnanto, 2007:323). Setelah pengakuan awal, dalam PSAK 16 menyatakan bahwa entitas dapat memilih model biaya (paragraf 30) atau model revaluasi (paragraf 31) sebagai kebijakan akuntansinya dan menerapkan kebijakan tersebut terhadap seluruh aset tetap dalam kelompok yang sama (PSAK 16 paragraf 29).

c. Penyajian dan Pengungkapan

Penyajian aset tetap terletak pada laporan posisi keuangan entitas kelompok aset tidak lancar. PSAK 16 menyatakan bahwa laporan keuangan harus mengungkapkan dasar pengukuran aset tetap yang digunakan dalam menentukan jumlah tercatat bruto, metode penyusutan yang digunakan, umur manfaat atau tarif penyusutan yang digunakan, jumlah tercatat bruto dan akumulasi penyusutan (dijumlahkan dengan akumulasi rugi penurunan nilai) pada awal dan akhir periode, dan rekonsiliasi jumlah tercatat pada awal dan akhir periode yang menunjukkan penambahan (PSAK 16 paragraf 74).

Laporan keuangan juga harus mengungkapkan keberadaan dan jumlah restriksi atas hak milik dan aset tetap yang dijaminkan untuk liabilitas, jumlah pengeluaran yang diakui dalam jumlah tercatat aset tetap yang sedang dalam pembangunan, jumlah komitmen kontraktual dalam perolehan aset tetap, dan jumlah kompensasi dari pihak ketiga untuk aset tetap (aset tetap yang mengalami penurunan nilai, hilang atau dihentikan yang dimasukkan dalam laba rugi) (PSAK 16 paragraf 75). Apabila entitas menyajikan dalam jumlah revaluasi, entitas diharapkan dapat mengungkapkan tanggal efektif revaluasi, ada atau tidaknya penilai independen, dan untuk setiap kelas aset yang direvaluasi diungkap jumlah tercatat dengan model biaya (apabila ada), dan surplus revaluasi (PSAK 16 paragraf 77). 
PSAK 14

PSAK 14 menyebutkan bahwa persediaan adalah aset yang tersedia untuk dijual dalam kegiatan usaha biasa, dalam proses produksi untuk penjualan tersebut atau dalam bentuk bahan atau perlengkapan untuk digunakan dalam proses produksi atau pemberian jasa (PSAK 14 paragraf 5).

a. Pengakuan

Suatu aset dapat diklasifikasikan sebagai persediaan bila memenuhi salah satu kriteria berikut: barang yang dibeli untuk dijual kembali, barang jadi yang diproduksi atau barang dalam penyelesaian yang sedang diproduksi termasuk bahan serta perlengkapan yang akan digunakan dalam proses produksi (PSAK 14 paragraf 7). Harnanto (2007:222) mendefinisikan persediaan meliputi barang yang dimiliki dengan tujuan untuk dijual kembali dan/ dikonsumsi dalam operasi normal perusahaan.

b. Pengukuran

Persediaan harus diukur berdasarkan biaya atau nilai realisasi neto, mana yang lebih rendah (PSAK 14 paragraf 8). Biaya persediaan harus meliputi biaya pembelian, biaya konversi, biaya lain yang timbul sampai persediaan berada dalam kondisi dan lokasi saat ini (PSAK 14 paragraf 9). Sedangkan nilai realisasi neto adalah estimasi harga jual dalam kegiatan usaha biasa dikurangi estimasi biaya penyelesaian dan estimasi biaya yang diperlukan untuk membuat penjualan (PSAK paragraf 5).

c. Penyajian dan Pengungkapan

Penyajian persediaan terletak pada laporan posisi keuangan entitas kelompok aset lancar. PSAK 14 paragraf 34 menyatakan bahwa laporan keuangan harus mengungkapka kebijakan akuntansi yang digunakan dalam pengukuran persediaan termasuk rumus biaya yang digunakan, jumlah tercatat persediaan dan jumlah nilai tercatat menurut klasifikasi yang sesuai bagi entitas, jumlah tercatat persediaan yang dicatat dengan nilai wajar dikurangi biaya untuk menjual, jumlah persediaan yang diakui sebagai beban selama periode berjalan, jumlah setiap penurunan nilai yang diakui sebagai pengurang, jumlah pemulihan nilai yang diakui sebagai pengurang, kondisi atau peristiwa penyebab terjadinya pemulihan nilai persediaan yang diturunkan, dan nilai tercatat persediaan yang diperuntukkan sebagai jaminan kewajiban.

\section{Kerangka Berpikir}

Perlakuan akuntansi mengenai aset biologis di Indonesia belum menggunakan standar khusus. Hal itu menarik bagi peneliti untuk mengetahui bagaimana perusahaan memperlakukan aset biologis dari pengakuan, pengukuran, penyajian dan pengungkapan. Selain itu, peneliti malakukan identifikasi standar apa yang digunakan oleh perusahaan dalam perlakuan akuntansi atas aset biologis perusahaan sampel kemudian membandingkan kesesuian perlakuan atas aset biologis dengan standar yang digunakan. Berikut kerangka berpikit dalam penelitian ini:

Gambar 2.1

Kerangka Berpikir

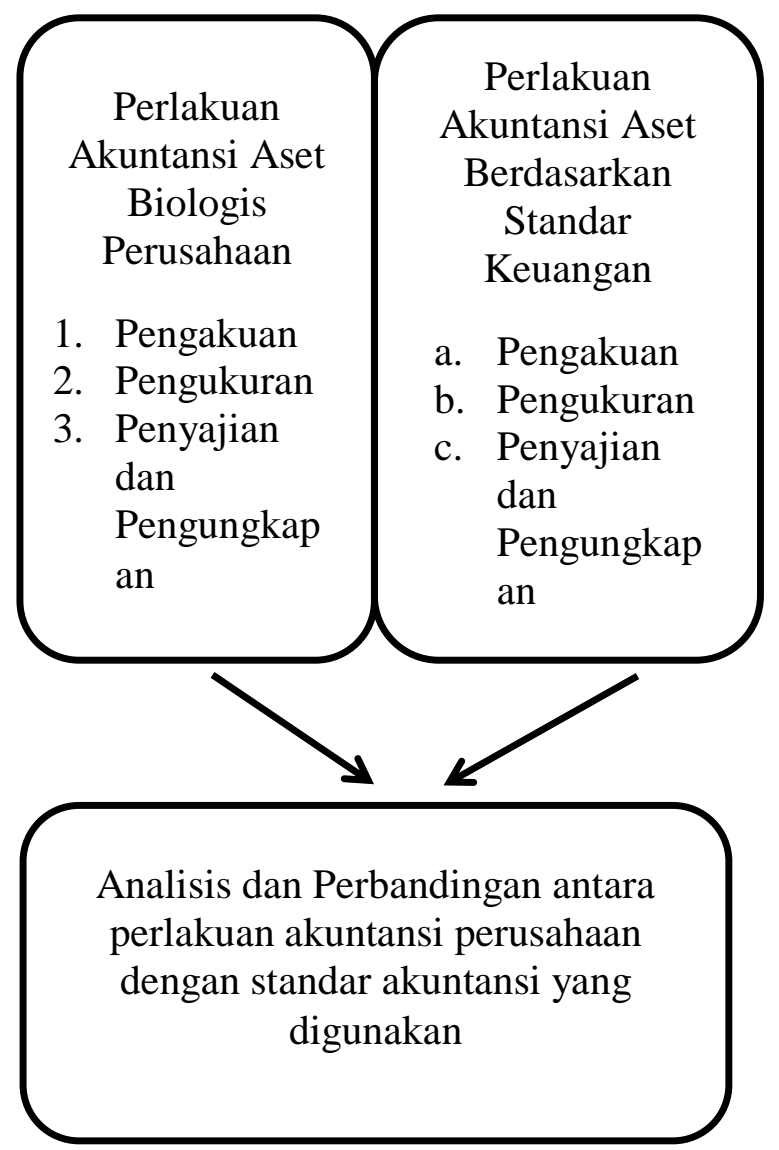

\section{METODE PENELITIAN.}

Populasi penelitian terdapat 16 perusahaan subsektor agrikultur yang terdaftar di Bursa Efek Indonesia. Tehnik pengambilan sampel dengan purposive sampling. Terdapat 14 perusahaan yang memenuhi kriteria sehingga sampel penelitian yaitu PT Astra Agro Lestari, Tbk (AALI), PT Austindo Nusantara Jaya, Tbk. (ANJT), PT Eagle High 
Plantations, Tbk. (BWPT), PT Dharma Satya Nusantara, Tbk. (DSNG), PT Golden Plantation, Tbk. (GOLL), PT Gozco Plantations, Tbk. (GZCO), PT J.A. Watti, Tbk. (JAWA), PT London Sumatra Indonesia, Tbk. (LSIP), PT Provident Agro, Tbk. (PALM), PT Sampoerna Agro, Tbk. (SGRO), PT Salim Ivomas Pratama, Tbk. (SIMP), PT Sinar Mas Agro Resources and Technology, Tbk. (SMAR), PT Tunas Baru Lampung, Tbk (TBLA), dan PT Bakrie Sumatera Plantations, Tbk. (UNSP).

Data penelitian yang digunakan data sekunder berupa laporan tahunan 2016 perusahaan subsektor perkebunan yang terdaftar di Bursa Efek Indonesia. data penelitian diperoleh dari website Bursa Efek Indonesia, www.idx.go.id, website setiap perusahaan dan berbagai sumber lain yang relevan dari buku, artikel, dan penelitian terdahulu yang terkait dengan perlakuan aset biologis. Penelitian bersifat deskriptif kualitatif yaitu dilakukan untuk memberikan gambaran mengenai perlakuan akuntansi aset biologis perusahaan subsektor agrikultur yang terdaftar di Bursa Efek Indonesia (BEI). Analisis data dilakukan dengan content analysis, yaitu menganalisis terhadap isi dari suatu dokumen untuk mengidentifikasi karakteristik atau informasi spesifik pada dokumen, sehingga menghasilkan deskripsi yang objektif dan sistematis(Indrianto dan Supomo, 2009 dalam Adita dan Kiswara, 2012). Content analysis dilakukan melalui laporan tahunan perusahaan dengan mengambil data yang diperlukan kemudian dianalisis. Tahap menganalisis perlakuan akuntansi atas aset biologis perusahaan mengklasifikasikan aset biologis, mengidentifikasi perlakuan akuntansi (pengakuan, pengukuran, penyajian, dan pengungkapan) aset biologis pada perusahaan, standar akuntansi yang digunakan oleh perusahaan kemudian melakuan perbandingan antara perlakuan akuntansi aset biologis perusahaan dengan standar akuntansi yang digunakan. Pengujian keabsahan dengan uji kredibilitas data pada penelitian ini menggunakan trianggulasi. Trianggulasi yang digunakan adalah trianggulasi sumber. Trianggulasi sumber merupakan pengumpulan data dilakukan di berbagai sumber untuk mendapatkan data yang lebih valid dan kredibel (Moleong, 2007:330). Trianggulasi yang dilakukan adalah dengan mengambil data dari berbagai sumber website Bursa Efek Indonesia (BEI) dan website masing-masing perusahaan dibandingkan untuk memperoleh data yang valid.

\section{PEMBAHASAN}

Perusahaan agrikultur subsektor perkebunan pada penelitian ini terdapat 14 perusahaan go public yang terdaftar di Bursa Efek Indonesia (BEI). Jenis tanaman dibedakan menjadi dua, yaitu:

\section{a. Tanaman Tahunan}

Tanaman tahunan adalah jenis aset biologis berupa tanaman yang memiliki jangka waktu lebih dari satu tahun (Korompis, 2014). Berikut adalah jenis aset biologis berupa tanaman tahunan yang dimiliki oleh perusahaan agrikultur subsektor perkebunan yang terdaftar di Bursa Efek Indonesia:

Tabel 4.1

Aset Biologis Perusahaan Berdasarkan Jenis Tanaman Tahunan

\begin{tabular}{|c|c|c|}
\hline No & Nama Perusahaan & $\begin{array}{c}\text { Komoditas } \\
\text { Tanaman Tahunan }\end{array}$ \\
\hline 1 & $\begin{array}{l}\text { PT Astra Agro } \\
\text { Lestari, Tbk } \\
\text { (AALI) }\end{array}$ & Sawit dan Karet \\
\hline 2 & $\begin{array}{l}\text { PT Austindo } \\
\text { Nusantara Jaya, } \\
\text { Tbk. (ANJT) }\end{array}$ & Sawit \\
\hline 3 & $\begin{array}{l}\text { PT Eagle High } \\
\text { Plantations, Tbk. } \\
\text { (BWPT) }\end{array}$ & $\begin{array}{l}\text { Sawit dan Bibit } \\
\text { Sawit }\end{array}$ \\
\hline 4 & $\begin{array}{l}\text { PT Dharma Satya } \\
\text { Nusantara, Tbk. } \\
\text { (DSNG) }\end{array}$ & $\begin{array}{l}\text { Sawit dan Kayu } \\
\text { atau Hutan } \\
\text { Tanaman Industri } \\
\text { (HTI) }\end{array}$ \\
\hline 5 & $\begin{array}{l}\text { PT Golden } \\
\text { Plantation, Tbk. } \\
\text { (GOLL) }\end{array}$ & Sawit \\
\hline 6 & $\begin{array}{l}\text { PT Gozco } \\
\text { Plantations, Tbk. } \\
\text { GZCO) }\end{array}$ & $\begin{array}{c}\text { Sawit dan Bibit } \\
\text { Sawit }\end{array}$ \\
\hline 7 & $\begin{array}{l}\text { PT Jaya Agra } \\
\text { Watti, Tbk. } \\
\text { (JAWA) }\end{array}$ & $\begin{array}{c}\text { Sawit, Bibit Sawit, } \\
\text { Karet, Kopi, Teh }\end{array}$ \\
\hline 8 & $\begin{array}{l}\text { PT London } \\
\text { Sumatra } \\
\text { Indonesia, Tbk. } \\
\text { (LSIP) }\end{array}$ & $\begin{array}{l}\text { Sawit, Bibit Sawit, } \\
\text { Karet, Kakao, Teh }\end{array}$ \\
\hline 9 & $\begin{array}{l}\text { PT Provident } \\
\text { Agro, Tbk. } \\
\text { (PALM) }\end{array}$ & $\begin{array}{c}\text { Sawit dan Bibit } \\
\text { Sawit }\end{array}$ \\
\hline 10 & $\begin{array}{l}\text { PT Sampoerna } \\
\text { Agro, Tbk. } \\
\text { (SGRO) }\end{array}$ & $\begin{array}{c}\text { Sawit, Karet, } \\
\text { Kecambah Sawit, } \\
\text { Hutan Tanaman } \\
\text { Industri (HTI) }\end{array}$ \\
\hline 11 & $\begin{array}{l}\text { PT Salim Ivomas } \\
\text { Pratama, Tbk. }\end{array}$ & $\begin{array}{l}\text { Sawit, Karet, Bibit } \\
\text { Sawit, Hutan }\end{array}$ \\
\hline
\end{tabular}




\begin{tabular}{|c|l|c|}
\hline 12 & $\begin{array}{c}\text { (SIMP) } \\
\text { PT Sinar Mas } \\
\text { Agro Resources } \\
\text { and Technology, } \\
\text { Tbk. (SMAR) }\end{array}$ & $\begin{array}{c}\text { Sawit dan Bibit } \\
\text { Sawit }\end{array}$ \\
\hline 13 & $\begin{array}{l}\text { PT Tunas Baru } \\
\text { Lampung, Tbk } \\
\text { (TBLA) }\end{array}$ & Sawit \\
\hline 14 & $\begin{array}{l}\text { PT Bakrie } \\
\text { Sumatera } \\
\text { Plantations, Tbk. } \\
\text { (UNSP) }\end{array}$ & Sawit dan Karet \\
\hline
\end{tabular}

Sumber : Laporan Tahunan, data diolah 2018

Berdasarkan tabel 4.1 diketahui perusahaan agrikultur subsektor perkebunan yang terdaftar di BEI memiliki tanaman tahunan mayoritas berupa sawit. Tanaman tahunan yang dimiliki perusahaan sampel berupa sawit, karet, hutan tanaman industri, teh, kopi, dan kakao.

\section{b. Tanaman Musiman}

Tanaman musiman adalah jenis aset biologis berupa tanaman yang memiliki jangka waktu kurang dari satu tahun (Korompis, 2014). Tanaman musiman dimiliki oleh dua perusahaan SIMP dan TBLA berupa tebu.

\section{Perlakuan Akuntansi Aset Biologis Perusahaan}

Berikut akan dibahas mengenai perlakuan aset biologis perusahaan agrikultur subsektor perkebunan meliputi pengakuan, pengukuran, penyajian, hingga pengungkapan berdasarkan jenis tanaman.

\section{a. Tanaman Tahunan \\ Pengakuan}

Tanaman tahunan perusahaan perkebunan dari 14 objek penelitian terdiri dari sawit, karet, kakao, kopi, teh, dan hutan tanaman industri. Aset biologis tersebut diakui sebagai Tanaman Belum Menghasilkan (TBM), Tanaman Menghasilkan (TM), dan persediaan. TBM diakui sejak dikeluarkan biaya untuk penanaman, kemudian diakui sebagai TM ketika tanaman telah mencapai umur atau waktu yang telah ditetapkan. Hasil panen asli maupun olahan diakui sebagai persediaan. Selain itu terdapat perusahaan yang mengelola aset biologis berupa bibitan seperti BWPT, JAWA, LSIP, dan SGRO. Bibitan yang dimiliki ada yang dijual dan digunakan oleh perusahaan itu sendiri. Bibitan yang dijual diakui sebagai aset tidak lancar lainnya. Berikut kriteria pengakuan tanaman menhasilkan dan persediaan tanaman tahunan perusahaan.

Tabel 4.3

Kriteria Pengakuan Tanaman Tahunan

\begin{tabular}{|c|c|c|}
\hline & $\begin{array}{c}\text { Tanaman } \\
\text { Menghasilkan }\end{array}$ & Persediaan \\
\hline Sawit & $\begin{array}{l}\text { Aset diakui sebagai } \\
\text { TM apabila telah } \\
\text { berumur 3-4 tahun } \\
\text { atau telah } \\
\text { mengahasilkan } \\
\text { Tandan Buah Segar } \\
\text { (TBS) 4-6 ton per } \\
\text { hektar dalam satu } \\
\text { tahun }\end{array}$ & $\begin{array}{lr}\text { Hasil } & \text { panen } \\
\text { berupa } & \text { TBS } \\
\text { dan produk } \\
\text { olahan seperti } \\
\text { minyak sawit } \\
\text { dan inti sawit. }\end{array}$ \\
\hline Karet & $\begin{array}{l}\text { Aset diakui sebagai } \\
\text { TM apabila telah } \\
\text { berumur 5-6 tahun. }\end{array}$ & $\begin{array}{lr}\text { Hasil } & \text { panen } \\
\text { berupa } & \text { getah } \\
\text { karet } & \text { dan } \\
\text { produk } & \\
\text { olahan. } & \end{array}$ \\
\hline Kakao & $\begin{array}{l}\text { Diakui sebagai TM } \\
\text { sesuai dengan waktu } \\
\text { yang telah } \\
\text { ditentukan } \\
\text { manajemen. }\end{array}$ & $\begin{array}{l}\text { Hasil panen } \\
\text { berupa kakao. }\end{array}$ \\
\hline Teh & $\begin{array}{l}\text { Diakui sebagai TM } \\
\text { sesuai dengan waktu } \\
\text { yang telah } \\
\text { ditentukan } \\
\text { manajemen. }\end{array}$ & $\begin{array}{l}\text { Hasil panen } \\
\text { berupa pucuk } \\
\text { daun teh. }\end{array}$ \\
\hline Kopi & $\begin{array}{l}\text { Diakui sebagai TM } \\
\text { sesuai dengan waktu } \\
\text { yang telah } \\
\text { ditentukan } \\
\text { manajemen. }\end{array}$ & $\begin{array}{lr}\text { Hasil } & \text { panen } \\
\text { berupa } & \text { biji } \\
\text { kopi } & \text { dan } \\
\text { produk } & \text { olahan } \\
\text { berupa kopi. }\end{array}$ \\
\hline $\begin{array}{l}\text { Hutan } \\
\text { Tanaman } \\
\text { Industri }\end{array}$ & $\begin{array}{l}\text { Diakui sebagai TM } \\
\text { sesuai dengan waktu } \\
\text { yang } \\
\text { ditentukan } \\
\text { manajemen. }\end{array}$ & $\begin{array}{lr}\text { Hasil panen } \\
\text { berupa kayu } \\
\text { dan produk } \\
\text { olahan. }\end{array}$ \\
\hline
\end{tabular}

Sumber : data diolah 2018

\section{Pengukuran}

Pengukuran aset biologis, TBM diukur berdasarkan harga perolehan. Harga perolehan meliputi persiapan lahan, penanaman, pemupukan, dan pemeliharaan termasuk kapitalisasi biaya pinjaman untuk pengembangan perkebunan dan 
biaya tidak langsung yang dialokasikan berdasarkan luas hektar tanaman.

TM diukur berdasarkan nilai reklasifikasi dari TBM ketika TBM diakui sebagai TM sesuai waktu yang telah diatur oleh pihak manajemen. Setalah pengakuan awal TM, TM dapat diukur berdasarkan model biaya dan model revaluasi. Terdapat 3 perusahaan di mana entitas anak mengukur dengan model revaluasi, yaitu GZCO, JAWA, dan PALM.

Model biaya mengukur TM berdasarkan harga perolehan dikurangi akumulasi penyusutan. Metode penyusutan yang digunakan adalah metode garis lurus dengan umur ekonomis yang ditaksir 20-30 tahun. Penyusutan yang terjadi akan mempengaruhi laporan laba rugi perusahaan sebagai beban umum dan administrasi.Model revaluasi mengukur nilai wajar dengan penilaian secara independen diukur berdasarkan nilai revaluasian. Pengukuran nilai wajar dengan pendekatan biaya dan pendekatan pendapatan. Nilai revaluasian GZCO tidak dilakukan pada tahun 2016, revaluasian JAWA lebih kecil daripada nilai tercatat sehingga dibebankan sebagai beban operasi lain yang akan mempengaruhi laporan laba rugi.

Persediaan diukur berdasarkan nilai yang lebih rendah antara harga perolehan dengan nilai realisasi bersih. Harga perolehan berupa biaya di perkebunan dan dialokasikan dengan luas lahan. Metode perhitungan biaya dengan metode rata-rata tertimbang, rata-rata bergerak, terdapat satu perusahaan menggunakan metode FIFO (First In First Out) yaitu GOLL.

\section{Penyajian dan Pengungkapan}

Aset biologis perusahaan berupa tanaman perkebunan yang diakui sebagai TBM dan TM disajikan dalam kelompok aset tidak lancar dan aset yang diakui sebagai persediaan disajikan dalam kelompok aset lancar. Aset berupa bibitan disajikan sebagai akun tersendiri, tanaman perkebunan, dan sebagai aset tidak lancar lainnya. Aset tersebut tersaji dalam laporan keuangan yaitu laporan posisi keuangan.

Perusahaan mengungkapkan informasi mengenai aset biologis berupa tanaman menghasilkan dan tanaman belum menghasilkan atau tanaman perkebunan meliputi jenis aset biologis, dasar pengukuran yang digunakan dalam menentukan jumlah tercatat, metode penyusutan dan umur manfaat aset biologis, jumlah tercatat bruto dikurangi akumulasi penyusutan pada awal dan akhir periode, rekonsiliasi jumlah tercatat pada awal dan akhir periode meliputi penambahan, perolehan penambahan karena adanya kombinasi bisnis, dan penyusutan. Perusahaan yang melakukan model revaluasi mengungkapakan informasi tambahan mengenai tanggal efektif, adanya penilai independen, dan jumlah revaluasi yang diakui.

Perusahaan juga mengungkapkan informasi mengenai aset berupa persediaan hasil aktivitas agrikultur atau perkebunan meliputi kebijakan akuntansi yang digunakan dalam mengukur persediaan beserta rumus biaya yang digunakan, jumlah tercatat persediaan, nilai persediaan AALI tidak mengalami penurunan nilai dan pemulihan nilai dan jumlah persediaan yang diakui sebagai beban pada periode berjalan.

\section{b. Tanaman Musiman \\ Pengakuan}

Terdapat dari dua perusahaan yang memiliki tanaman musiman berupa tebu yaitu TBLA dan SIMP. Aset biologis tebu TBLA diakui sebagai tanaman tebu tangguhan. Beban ini mengakui beban yang tidak lancar terkait pengelolaan tebu. Untuk beban yang termasuk dalam klasifikasi tidak lancar diakui sebagai aset tidak lancar lainnya, seperti beban persiapan lahan dan penanaman. Tebu SIMP diakui sebagai persediaan. Persediaan berupa gula dan bahan pendukung lain terkait aktivitas agrikultur tebu. Hasil olahan tebu oleh TBLA dijual.

\section{Pengukuran}

Pengukuran tebu SIMP dan TBLA berdasarkan pada harga perolehan. Tebu SIMP sebagai tanaman tebu tangguhan akan dibebankan pada laporan laba rugi ketika sudah panen. Beban yang dikeluarkan terkait tebu dan terklasifikasi tidak lancar tidak dibebankan pada beban tanaman tebu tangguhan tetapi pada aset tidak lancar lainnya, seperti persiapan lahan dan penanaman. Tebu TBLA sebesar biaya yang dikeluarkan untuk pembibitan atau pembelian bibit dan penanaman sampai tebu siap panen. Tebu yang telah dipanen diolah menjadi gula kemudian dijual. Biaya-biaya atau persediaan yang telah menjadi beban 
dibebankan pada beban pokok penjualan. Beban pokok penjualan mempengaruhi laporan laba rugi komprehensif perusahaan.

\section{Penyajian dan Pengungkapan}

Tebu yang dimiliki SIMP dan TBLA disajikan dalam laporan posisi keuangan kelompok aset lancar. SIMP dan TBLA mengungkapkan informasi mengenai jenis aset biologis, dasar pengukuran yang digunakan dalam menentukan jumlah tercatat, dan jumlah tercatat pada awal dan akhir periode.

\section{Standar Akuntansi yang digunakan}

Standar akuntansi yang digunakan oleh perusahaan agrikultur subsektor perkebunan untuk memerlakukan aset biologis yang dimiliki berdasarkan PSAK No 14 mengenai persediaan dan PSAK No 16 mengenai aset tetap. 
Perbandingan Perlakuan Akuntansi Aset Biologis Perusahaan dengan Standar yang digunakan

Berikut memaparkan perbandingan pengakuan aset biologis tanaman tahunan perusahaan dengan standar akuntansi keuangan yang digunakan:

Tabel 4.5

Perbandingan Pengakuan Aset Biologis Perusahaan Menurut PSAK

\begin{tabular}{|c|c|c|c|c|}
\hline No & $\begin{array}{l}\text { Kode } \\
\text { Perusah } \\
\text { aan }\end{array}$ & Perusahaan & PSAK & Kesesuaian \\
\hline 1 & AALI & $\begin{array}{l}\text { a. Aset biologis diakui sebagai persedian berupa hasil } \\
\text { sawit dan karet berserta olahan dengan kriteria bahan } \\
\text { atau aset yang digunakan dalam proses produksi dan } \\
\text { barang jadi untuk dijual. } \\
\text { b. Aset biologis berupa sawit dan karet diakui sebagai } \\
\text { tanaman menghasilkan dan belum menghasilkan dengan } \\
\text { ketentuan waktu TBM menjadi TM untuk sawit 3-4 } \\
\text { tahun dan karet 5-6 tahun. }\end{array}$ & \multirow{4}{*}{ 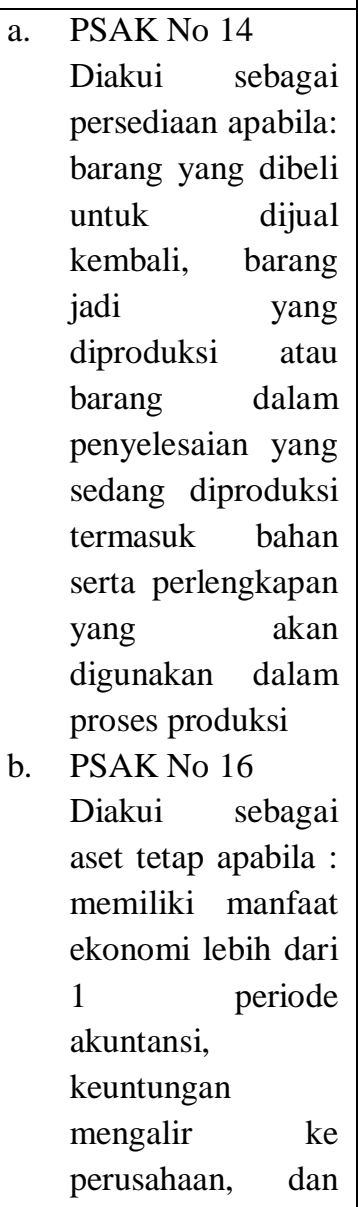 } & $\begin{array}{l}\text { a. Sesuai dengan PSAK } 14 \text { karena telah memenuhi salah } \\
\text { satu kriteria diakui sebagai persediaan yaitu sebagai } \\
\text { bahan yang digunakan dalam proses produksi dan } \\
\text { sebagai barang jadi setelah produksi. } \\
\text { b. Sesuai PSAK } 16 \text { karena telah memenuhi kriteria atau } \\
\text { unsur diakui sebagai aset tetap seperti yang dijelaskan } \\
\text { dalam PSAK 16. }\end{array}$ \\
\hline 2 & ANJT & $\begin{array}{l}\text { a. Aset biologis diakui sebagai persediaan dengan kriteria } \\
\text { bahan atau aset yang digunakan dalam proses produksi } \\
\text { dan barang jadi berupa TBS dan hasil olahan. } \\
\text { b. Aset biologis berupa sawit diakui sebagai tanaman } \\
\text { menghasilkan dan belum menghasilkan dengan } \\
\text { ketentuan waktu 3-4 tahun atau menghasilkan 3,5 ton } \\
\text { per hektar setahun. }\end{array}$ & & $\begin{array}{l}\text { a. Sesuai dengan PSAK } 14 \text { karena telah memenuhi salah } \\
\text { satu kriteria diakui sebagai persediaan yaitu sebagai } \\
\text { bahan yang digunakan dalam proses produksi dan } \\
\text { barang jadi. } \\
\text { b. Sesuai PSAK } 16 \text { karena telah memenuhi kriteria atau } \\
\text { unsur diakui sebagai aset tetap seperti yang dijelaskan } \\
\text { dalam PSAK 16. }\end{array}$ \\
\hline 3 & BWPT & $\begin{array}{l}\text { a. Aset biologis diakui sebagai persedian dengan kriteria } \\
\text { barang atau bahan untuk proses produksi dan barang } \\
\text { jadi yang siap dijual berupa minyak sawit dan inti sawit. } \\
\text { b. Aset biologis berupa sawit diakui sebagai tanaman } \\
\text { menghasilkan, belum menghasilkan, TBM menjadi TM } \\
\text { ketika ketentuan waktu telah mencapai } 4 \text { tahun dan } \\
\text { bibitan diakui sebagai tanaman perkebunan yang akan } \\
\text { direklasifikasi ke TBM. }\end{array}$ & & $\begin{array}{l}\text { a. Sesuai dengan PSAK } 14 \text { karena telah memenuhi } \\
\text { kriteria diakui sebagai persediaan yaitu sebagai bahan } \\
\text { yang digunakan dalam proses produksi dan barang } \\
\text { jadi. } \\
\text { b. Sesuai PSAK } 16 \text { karena telah memenuhi kriteria atau } \\
\text { unsur diakui sebagai aset tetap seperti yang dijelaskan } \\
\text { dalam PSAK 16. }\end{array}$ \\
\hline 4 & DSNG & $\begin{array}{l}\text { a. Aset biologis diakui sebagai persediaan dengan kriteria } \\
\text { bahan atau aset yang digunakan dalam proses produksi } \\
\text { dan barang jadi berupa minyak sawit dan inti sawit }\end{array}$ & & $\begin{array}{l}\text { a. Sesuai dengan PSAK } 14 \text { karena telah memenuhi salah } \\
\text { satu kriteria diakui sebagai persediaan yaitu sebagai } \\
\text { bahan yang digunakan dalam proses produksi dan }\end{array}$ \\
\hline
\end{tabular}


Wulandari, Wijayati/ 2018

\begin{tabular}{|c|c|c|c|c|c|}
\hline & & \begin{tabular}{|l} 
serta turunannya. \\
b. Aset biologis berupa sawit dan HTI diakui sebagai \\
tanaman menghasilkan dan belum menghasilkan dengan \\
ketentuan waktu TBM menjadi TM untuk sawit 3 tahun.
\end{tabular} & \multirow[t]{5}{*}{$\begin{array}{lr}\text { biaya } & \text { perolehan } \\
\text { dapat } & \text { terukur } \\
\text { dengan } & \text { andal. }\end{array}$} & & $\begin{array}{l}\text { barang jadi. } \\
\text { Sesuai PSAK } 16 \text { karena telah memenuhi kriteria atau } \\
\text { unsur diakui sebagai aset tetap seperti yang dijelaskan } \\
\text { dalam PSAK } 16 .\end{array}$ \\
\hline 5 & GOLL & $\begin{array}{l}\text { a. Aset biologis diakui sebagai persedian dengan kriteria } \\
\text { bahan atau aset yang digunakan dalam proses produksi } \\
\text { dan barang jadi berupa minyak sawit, inti sawit, dan } \\
\text { minyak inti sawit. Bibit GOLL diakui sebagai } \\
\text { persediaan dengan kriteria digunakan untuk proses } \\
\text { produksi. } \\
\text { b. Aset biologis berupa sawit diakui sebagai tanaman } \\
\text { menghasilkan dan belum menghasilkan dengan } \\
\text { ketentuan waktu TBM menjadi TM } 5 \text { tahun. }\end{array}$ & & & $\begin{array}{l}\text { Sesuai dengan PSAK } 14 \text { karena telah memenuhi salah } \\
\text { satu kriteria diakui sebagai persediaan yaitu sebagai } \\
\text { bahan yang digunakan dalam proses produksi dan } \\
\text { barang jadi. } \\
\text { Sesuai PSAK } 16 \text { karena telah memenuhi kriteria atau } \\
\text { unsur diakui sebagai aset tetap seperti yang dijelaskan } \\
\text { dalam PSAK } 16 \text {. }\end{array}$ \\
\hline 6 & GZCO & $\begin{array}{l}\text { a. Aset biologis diakui sebagai persedian dengan kriteria } \\
\text { bahan atau aset yang digunakan dalam proses produksi } \\
\text { berupa minyak sawit. Bibit GZCO diakui sebagai } \\
\text { persediaan dengan kriteria tersedia untuk dijual. } \\
\text { b. Aset biologis berupa sawit diakui sebagai tanaman } \\
\text { menghasilkan dan belum menghasilkan dengan } \\
\text { ketentuan waktu TBM menjadi TM } 5 \text { tahun. }\end{array}$ & & & $\begin{array}{l}\text { Sesuai dengan PSAK } 14 \text { karena telah memenuhi salah } \\
\text { satu kriteria diakui sebagai persediaan yaitu sebagai } \\
\text { bahan yang digunakan dalam proses produksi dan } \\
\text { barang tersedia untuk dijual. } \\
\text { Sesuai PSAK } 16 \text { karena telah memenuhi kriteria atau } \\
\text { unsur diakui sebagai aset tetap seperti yang dijelaskan } \\
\text { dalam PSAK } 16 \text {. }\end{array}$ \\
\hline 7 & JAWA & $\begin{array}{l}\text { a. Aset biologis diakui sebagai persedian dengan kriteria } \\
\text { bahan atau aset yang digunakan dalam proses produksi } \\
\text { dan ada yang berupa barang siap dijual berupa minyak } \\
\text { sawit dan inti sawit, karet, kopi, dan pucuk daun teh. } \\
\text { b. Aset biologis berupa sawit, karet, kopi, dan teh diakui } \\
\text { sebagai tanaman menghasilkan dan belum } \\
\text { menghasilkan dengan ketentuan waktu TBM menjadi } \\
\text { TM untuk sawit } 4 \text { tahun dan karet 5-6 tahun. } \\
\text { Bibit diakui sebagai akun bibit kelompok aset tidak lancar } \\
\text { dengan ketentuan direklasifikasi ke TBM. }\end{array}$ & & & $\begin{array}{l}\text { Sesuai dengan PSAK } 14 \text { karena telah memenuhi salah } \\
\text { satu kriteria diakui sebagai persediaan yaitu sebagai } \\
\text { bahan yang digunakan dalam proses produksi dan } \\
\text { barang jadi. } \\
\text { Sesuai PSAK } 16 \text { karena telah memenuhi kriteria atau } \\
\text { unsur diakui sebagai aset tetap seperti yang dijelaskan } \\
\text { dalam PSAK } 16 \text {. }\end{array}$ \\
\hline 8 & LSIP & $\begin{array}{l}\text { a. Aset biologis diakui sebagai persedian dengan kriteria } \\
\text { bahan atau aset yang digunakan dalam proses produksi } \\
\text { dan barang jadi yang siap dijual berupa minyak sawit }\end{array}$ & & & $\begin{array}{l}\text { Sesuai dengan PSAK } 14 \text { karena telah memenuhi salah } \\
\text { satu kriteria diakui sebagai persediaan yaitu sebagai } \\
\text { bahan yang digunakan dalam proses produksi. }\end{array}$ \\
\hline
\end{tabular}




\begin{tabular}{|c|c|c|c|}
\hline & & $\begin{array}{l}\text { dan inti sawit serta turunannya, karet, kakao, dan pucuk } \\
\text { daun teh. } \\
\text { b. Aset biologis berupa sawit, karet, kakao, dan teh diakui } \\
\text { sebagai tanaman menghasilkan dan belum } \\
\text { menghasilkan dengan ketentuan waktu TBM menjadi } \\
\text { TM untuk sawit 3-4 tahun dan karet 5-6 tahun. } \\
\text { Bibit sawit diakui sebagai aset tidak lancar lainnya dengan } \\
\text { ketentuan untuk dijual. }\end{array}$ & $\begin{array}{l}\text { b. Sesuai PSAK } 16 \text { karena telah memenuhi kriteria atau } \\
\text { unsur diakui sebagai aset tetap seperti yang dijelaskan } \\
\text { dalam PSAK } 16 \text {. }\end{array}$ \\
\hline 9 & PALM & $\begin{array}{l}\text { a. Aset biologis diakui sebagai persedian dengan kriteria } \\
\text { bahan atau aset yang digunakan dalam proses produksi } \\
\text { berupa minyak sawit dan inti sawit. } \\
\text { b. Aset biologis berupa sawit diakui sebagai tanaman } \\
\text { menghasilkan dan belum menghasilkan dengan } \\
\text { ketentuan waktu TBM menjadi TM 3-4 tahun. } \\
\text { Bibit sawit diakui sebagai bibit kelompok aset tidak lancar } \\
\text { dan akan direklasifikasi ke TBM. }\end{array}$ & $\begin{array}{l}\text { a. Sesuai dengan PSAK } 14 \text { karena telah memenuhi salah } \\
\text { satu kriteria diakui sebagai persediaan yaitu sebagai } \\
\text { bahan yang digunakan dalam proses produksi. } \\
\text { b. Sesuai PSAK } 16 \text { karena telah memenuhi kriteria atau } \\
\text { unsur diakui sebagai aset tetap seperti yang dijelaskan } \\
\text { dalam PSAK 16. }\end{array}$ \\
\hline 10 & SGRO & $\begin{array}{l}\text { a. Aset biologis diakui sebagai persedian dengan kriteria } \\
\text { bahan atau aset yang digunakan dalam proses produksi } \\
\text { dan barang yang siap untuk dijual berupa minyak sawit } \\
\text { dan inti sawit serta turunannya, karet, dan bibit sawit. } \\
\text { b. Aset biologis berupa sawit dan diakui sebagai tanaman } \\
\text { menghasilkan dan belum menghasilkan dengan } \\
\text { ketentuan waktu TBM menjadi TM untuk sawit } 4 \text { tahun } \\
\text { dan karet 5-6 tahun. } \\
\text { Bibit sawit diakui sebagai akun sendiri kelompok aset tidak } \\
\text { lancar. }\end{array}$ & $\begin{array}{l}\text { a. Sesuai dengan PSAK 14 karena telah memenuhi salah } \\
\text { satu kriteria diakui sebagai persediaan yaitu sebagai } \\
\text { bahan yang digunakan dalam proses produksi dan } \\
\text { sebagai barang yang siap dijual. } \\
\text { b. Sesuai PSAK 16 karena telah memenuhi kriteria atau } \\
\text { unsur diakui sebagai aset tetap seperti yang dijelaskan } \\
\text { dalam PSAK 16. }\end{array}$ \\
\hline 11 & SIMP & $\begin{array}{l}\text { a. Aset biologis diakui sebagai persedian dengan kriteria } \\
\text { bahan atau aset yang digunakan dalam proses produksi } \\
\text { dan barang yang siap untuk dijual berupa minyak sawit } \\
\text { dan inti sawit serta turunannya, bibit sawit, karet, dan } \\
\text { gula. } \\
\text { b. Aset biologis berupa sawit, HTI, dan karet diakui } \\
\text { sebagai tanaman menghasilkan dan belum }\end{array}$ & $\begin{array}{l}\text { a. Sesuai dengan PSAK } 14 \text { karena telah memenuhi salah } \\
\text { satu kriteria diakui sebagai persediaan yaitu sebagai } \\
\text { bahan yang digunakan dalam proses produksi dan } \\
\text { sebagai barang yang siap dijual } \\
\text { b. Sesuai PSAK } 16 \text { karena telah memenuhi kriteria atau } \\
\text { unsur diakui sebagai aset tetap seperti yang dijelaskan } \\
\text { dalam PSAK 16. }\end{array}$ \\
\hline
\end{tabular}




\begin{tabular}{|c|c|c|c|}
\hline & & $\begin{array}{l}\text { menghasilkan dengan ketentuan waktu TBM menjadi } \\
\text { TM untuk sawit 3-4 tahun dan karet 5-6 tahun. } \\
\text { Bibit sawit diakui sebagai aset tidak lancar lainnya dengan } \\
\text { ketentuan untuk dijual. }\end{array}$ & \\
\hline 12 & SMAR & $\begin{array}{l}\text { a. Aset biologis diakui sebagai persedian dengan kriteria } \\
\text { bahan atau aset yang digunakan dalam proses produksi } \\
\text { berupa minyak sawit dan inti sawit serta turunannya. } \\
\text { b. Aset biologis berupa sawit diakui sebagai tanaman } \\
\text { menghasilkan dan belum menghasilkan dengan } \\
\text { ketentuan waktu TBM menjadi TM } 4 \text { tahun. } \\
\text { Bibitan yang dimiliki diakui sebagai aset lain dan akan } \\
\text { direklafikasi ke TBM. }\end{array}$ & $\begin{array}{ll}\text { a. } & \text { Sesuai dengan PSAK } 14 \text { karena telah memenuhi salah } \\
\text { satu kriteria diakui sebagai persediaan yaitu sebagai } \\
\text { bahan yang digunakan dalam proses produksi. } \\
\text { b. Sesuai PSAK } 16 \text { karena telah memenuhi kriteria atau } \\
\text { unsur diakui sebagai aset tetap seperti yang dijelaskan } \\
\text { dalam PSAK 16. }\end{array}$ \\
\hline 13 & TBLA & $\begin{array}{l}\text { a. Aset biologis diakui sebagai persedian dengan kriteria } \\
\text { bahan atau aset yang digunakan dalam proses produksi } \\
\text { dan barang yang siap dijual berupa minyak sawit dan } \\
\text { inti sawit serta turunannya. Tanaman musiman diakui } \\
\text { sebagai persediaan dengan kriteria untuk proses dan } \\
\text { dijual. } \\
\text { b. Aset biologis berupa sawit diakui sebagai tanaman } \\
\text { menghasilkan dan belum menghasilkan dengan } \\
\text { ketentuan waktu TBM menjadi TM 4-5 tahun. }\end{array}$ & $\begin{array}{l}\text { a. Sesuai dengan PSAK 14 karena telah memenuhi salah } \\
\text { satu kriteria diakui sebagai persediaan yaitu sebagai } \\
\text { bahan yang digunakan dalam proses produksi dan } \\
\text { sebagai barang yang siap dijual. } \\
\text { b. Sesuai PSAK 16 karena telah memenuhi kriteria atau } \\
\text { unsur diakui sebagai aset tetap seperti yang dijelaskan } \\
\text { dalam PSAK 16. }\end{array}$ \\
\hline 14 & UNSP & $\begin{array}{l}\text { a. Aset biologis diakui sebagai persedian dengan kriteria } \\
\text { bahan atau aset yang digunakan dalam proses produksi } \\
\text { berupa minyak sawit, inti sawit serta turunannya dan } \\
\text { karet. } \\
\text { b. Aset biologis berupa sawit dan karet diakui sebagai } \\
\text { tanaman menghasilkan dan belum menghasilkan dengan } \\
\text { ketentuan waktu TBM menjadi TM berdasarkan } \\
\text { presentase. }\end{array}$ & $\begin{array}{l}\text { a. Sesuai dengan PSAK } 14 \text { karena telah memenuhi salah } \\
\text { satu kriteria diakui sebagai persediaan yaitu sebagai } \\
\text { bahan yang digunakan dalam proses produksi. } \\
\text { b. Sesuai PSAK } 16 \text { karena telah memenuhi kriteria atau } \\
\text { unsur diakui sebagai aset tetap seperti yang dijelaskan } \\
\text { dalam PSAK 16. }\end{array}$ \\
\hline
\end{tabular}

Berdasarkan tabel 4.5 dapat disimpulkan bahwa perlakuan akuntansi aset biologis dalam hal pengakuan telah sesuai dengan standar akuntansi keuangan yang digunakan dan berlaku. Secara keseluruhan aset biologis perusahaan berupa tanaman tahunan seperti sawit, karet, kakao, kopi, teh, hutan tanaman industri, dan bibitan. 
Tanaman tahunan selain bibitan diakui sesuai ketentuan PSAK No. 16 dan untuk hasil panen dan hasil olahan tanaman tahunan diakui sebagai persediaan PSAK No. 14. Bibitan yang dimiliki perusahaan ada yang diakui sebagai akun tersendiri, persediaan, tanaman perkebunan, dan aset tidak lancar lainnya. Perbedaan pengakuan tersebut disesuaikan dengan sifat dan fungsi aset itu sendiri dalam perusahaan.

Aset yang diakui sebagai persediaan menurut PSAK No. 14 apabila memenuhi salah salah satu kriteria yang ditentukan. Aset pada perusahaan agrikultur subsektor perkebunan diakui sebagai persediaan memiliki kriteria yaitu sebagai bahan dalam proses produksi dan menjadi barang yang siap untuk dijual.

Aset yang diakui sebagai aset tetap menurut PSAK No. 16 adalah memiliki masa manfaat lebih dari satu tahun di mana keuntungan dapat mengalir ke perusahaan. Tanaman yang diakui sebagai aset tetap dan diperlakukan sesuai PSAK No. 16 adalah tanaman tahunan.

\section{Tanaman Musiman}

Tanaman musiman dimiliki oleh SIMP dan TBLA berupa tebu. SIMP mengakui tebu sebagai beban tanaman tebu ditangguhkan dan TBLA mengakui tebu sebagai persediaan. Tebu diakui sejak biaya telah dikeluarkan untuk pengelolaan tebu. Beban tanaman tebu ditangguhkan berarti biaya-biaya yang dikeluarkan oleh perusahaan untuk tebu belum menjadi beban pada periode berjalan. Biaya yang diakui SIMP pada pos ini adalah biayabiaya yang dikeluarkan terkait tebu kecuali biaya persiapan lahan dan penanaman. Biaya persiapan lahan dan penanaman diakui sebagai aset tidak lancar lainnya. Beban tanaman tebu ditangguhkan akan menjadi pengurang penghasilan di laporan laba rugi ketika tebu telah dipanen sebagai beban pokok penjualan.

TBLA mengakui tebu sebagai persediaan dengan ketentuan diproses dan dijual setelah panen, sehingga perlakuan akuntansi disesuaikan dengan PSAK No. 14. Tebu yang diakui sebagai persediaan mengakui bahwa akibat aktivitas tebu akan diperoleh masa manfaat di masa datang. Tebu diakui sebagai persediaan karena memenuhi kriteria sebagai barang jadi yang siap dijual dan sebagai bahan untuk proses produksi. Hasil penjualan tebu atau olahan tebu yang dijual akan masuk dalam laporan laba rugi sebagai penjualan, tebu yang menjadi persediaan akan mempengaruhi laporan laba rugi sebagai beban pokok penjualan. Berdasarkan telaah beberapa literatur, beban yang ditangguhkan diakui sebagai aktiva tak berwujud (Syakur, 2015:313; Harnanto, 2007: 406) dan diakui sebagai aktiva lain-lain dalam Rahardjo, 2009:24. Sehingga, pengakuan tebu sebagai beban tanaman tebu ditangguhkan kurang relevan karena dalam SIMP beban tanaman tebu ditangguhkan diakui sebagai kelompok aset lancar. Meskipun, biaya tersebut akan terealisasi menjadi beban kurang dari satu periode akuntansi atau 12 bulan.

\section{Pengukuran}

\section{a. Tanaman Tahunan}

Berdasarkan perbandingan pengukuran tanaman tahunan perusahaan agrikultur subsektor perkebunan, untuk persediaan perusahaan mengukur dengan memilih nilai terendah dari nilai realisasi bersih dengan harga perolehan sesuai dengan PSAK No. 14. Kemudian, untuk pengukuran terhadap aset biologis khususnya yang diakui sebagai tanaman menghasilkan sebagian besar menggunakan pengukuran dengan model biaya dimana diukur berdasarkan harga perolehan dikurangi akumulasi penyusutan. Namun, juga terdapat perusahaan yang mengukur dengan model revaluasi yang nantinya akan mempengaruhi laporan laba rugi yaitu GZCO, JAWA, dan PALM. Pengukuran yang dilakukan sesuai dengan PSAK No. 16. Perusahaan yang memiliki bibitan dan hutan tanaman industri diukur berdasarkan harga perolehan.

\section{b. Tanaman Musiman}

Perusahaan yang memiliki tanaman musiman adalah SIMP dan TBLA. Walaupun keduanya mengakui tebu atau tanaman musiman berbeda namun pengukuran terhadap aset biologis berupa tebu yang dimiliki sama. Pengukuran tebu SIMP dan TBLA adalah berdasarkan harga perolehan. Harga perolehan pada SIMP yang diakui sebagai beban tanaman tangguhan adalah biaya yang dikeluarkan dalam pengelolaan tebu selain untuk persiapan lahan, biaya persiapan lahan dibebankan pada tanaman perkebunan. Sedangkan untuk TBLA tebu diukur berdasarkan harga perolehan atau biaya yang dikeluarkan untuk pengelolaan tebu.

\section{Penyajian dan Pengungkapan \\ Penyajian}

\section{a. Tanaman Tahunan}

Berdasarkan perbandingan penyajian aset biologis perusahaan agrikultur subsektor perkebunan disajikan dalam laporan posisi 
keuangan. tanaman tahunan disajikan dalam kelompok aset tidak lancar. Aset biologis tanaman tahunan disajikan dalam pos tanaman perkebunan untuk Tanaman Belum Menghasilkan (TBM), Tanaman Menghasilkan (TM), dan Hutan Tanaman Industri (HTI). Perusahaan yang memiliki bibitan menyajikan bibitan dengan berbagai cara, sebagai pos tersendiri, tanaman perkebunan, atau sebagai aset lain/aset tidak lancar. Perbedaan penyajian tergantung pada penilaian manajemen mengenai bibitan. Hasil dari kegiatan agrikultur yang sering disebut sebagai produk agrikultural disajikan sebagai persedian kelompok aset lancar.

b. Tanaman Musiman

Tanaman musiman yang dimiliki oleh SIMP dan TBLA disajikan pada laporan posisi keuangan kelompok aset lancar. Namun, keduanya tersaji dalam pos yang berbeda. Tebu yang dimiliki SIMP disajikan sebagai beban tanaman tebu ditangguhkan dan tebu yang dimiliki TBLA diakui sajikan pada pos persediaan. SIMP menyajikan tebu yang dimiliki dalam pos beban tanaman tebu ditangguhkan sebagai aset lancar karena manfaat akan diperoleh tidak lebih dari 1 tahun untuk biaya-biaya yang dikeluarkan selain biaya persiapan lahan dan penanaman yang disajikan dalam aset tidak lancar lainnya.

\section{Pengungkapan}

Berdasarkan perbandingan pengungkapan perusahaan telah sesuai dengan ketentuan PSAK No 14. Informasi tersebut diperoleh dari laporan keuangan perusahaan, terutama dalam catatan atas laporan keuangan.

Berdasarkan tabel 4.9 diketahui bahwa perusahaan agrikultur subsektor perkebunan telah mengungkapan informasi sesuai dengan ketentuan PSAK No 16 dan PSAK No 14. Aset biologis atau aktivitas agrikultur yang diperlakukan tidak berdasarkan PSAK No 16 dan PSAK No 14 diperlakukan berdasarkan Standar Akuntansi Keuangan (SAK) yang berlaku. Informasi mengenai pengungkapan atas aktivitas agrikultur aset biologis diperoleh dari laporan keuangan perusahaan, terutama dalam catatan atas laporan keuangan. Beban yang ditangguhkan diakui sebagai aktiva tak berwujud (Syakur, 2015:313).

\section{SIMPULAN}

Perlakuan aset biologis berupa tanaman perkebunan terdapat dua jenis, yaitu tanaman tahunan (jangka panjang) dan tanaman musiman (jangka pendek). Perlakuan akuntansi (pengakuan, pengukuran, penyajian, dan pengungkapan) yang dilakukan perusahaan adalah tanaman tahunan yang dimiliki oleh perusahaan diakui sebagai tanaman belum menghasilkan dan tanaman menghasilkan, selain itu juga terdapat perusahaan yang memiliki hutan tanaman industri yang juga diakui sebagai tanaman perkebunan tahunan. Beberapa perusahaan mengakui bibitan. Pengakuan tanaman belum menghasilkan ke tanaman menghasilkan dilakukan dengan jangka waktu yang telah ditentukan oleh manajemen. Tanaman musiman perusahaan dimiliki oleh dua perusahaan SIMP dan TBLA, aset biologis tersebut adalah tebu. SIMP mengakui tebu sebagai beban tanaman tebu ditangguhkan dan TBLA mengakui tebu sebagai persediaan. Hasil dari tanaman perkebunan berupa produk agrikultural diakui sebagai persediaan.

Pengukuran aset biologis tanaman perkebunan khususnya tanaman menghasilkan tidak sama untuk semua perusahaan. Pengukuran tanaman perkebunan untuk tanaman belum menghasilkan diukur berdasarkan harga perolehan dan tanaman menghasilkan pada awalnya diukur berdasarkan harga perolehan, setelah itu ada yang menggunakan harga perolehan dan ada yang mengukur dengan nilai wajar (model biaya atau model revaluasi). Pengukuran dengan harga perolehan dilakukan dengan biaya perolehan dikurangi akumulasi penyusutan. Pengukuran dengan nilai wajar di beberapa perusahaan sampel dilakukan dengan perhitungan berdasarkan arus kas didiskontokan oleh pihak independen atau penilai yang ditunjuk perusahaan. Dari 14 perusahaan terdapat 3 perusahaan menggunakan model biaya yaitu GZCO, JAWA, dan PALM selain itu menggunakan model biaya. Pengukuran tanaman musiman menggunakan harga perolehan.

Penyajian aset biologis terdapat dalam laporan posisi keuangan di mana untuk persediaan dan tanaman musiman dalam kelompok aset lancar dan untuk tanaman tahunan masuk dalam kelompok aset tidak lancar. Pengungkapan aset biologis tanaman perkebunan dilakukan untuk memberikan informasi mendalam kepada pemangku informasi. Poin-poin yang diungkapkan adalah jenis dan jumlah aset biologis, perusahaan mengungkapan informasi aset biologis tidak hanya sampai pada titik panen 
namun hingga diolah menjadi barang jadi, mengungkapkan dasar pengukuran yang digunakan dalam menentukan jumlah tercatat, dan mengungkapkan penyusutan (metode, umur ekonomis, tarif penyusutan yang digunakan).

Standar akuntansi keuangan yang digunakan oleh perusahaan agrikultur subsektor perkebunan adalah mengacu pada standar yang dibuat oleh Ikatan Akuntan Indonesia. Perlakuan aset biologis berupa tanaman perkebunan khususnya tanaman tahunan disesuaikan dengan standar akuntansi keuangan tentang aset tetap yaitu PSAK Nomor 16. Tanaman musiman TBLA berdasarkan PSAK No. 14 mengenai persediaan. Produk agrikultur diperlakukan sesuai dengan standar akuntansi keuangan tentang persediaan yaitu PSAK Nomor 14 .

Berdasarkan perbandingan yang telah dilakukan dalam perlakuan aset biologis perusahaan agrikultur subsektor perkebunan dengan standar akuntansi keuangan, dari pengakuan, pengukuran, hingga penyajian dan pengungkapan telah sesuai dengan standar yang berlaku yaitu PSAK Nomor 14 dan PSAK Nomor 16. Perlakuan akuntansi aset biologis sesuai dengan PSAK No 16 karena:

a. Aset biologis berupa tanaman tahunan memiliki kemungkinan mengalirkan manfaat ke perusahaan (manfaat lebih dari satu tahun), memiliki bentuk fisik, dimiliki dan dikuasai perusahaan dan biaya perolehan dapat terukur dengan andal.

b. Pengukuran awal aset biologis tanaman perkebunan menggunakan dengan biaya perolehan, pengukuran setelah pengakuan awal dapat memilih antara model biaya dan revaluasi pada tanaman menghasilkan. Pengukuran dengan model revaluasi dilakukan oleh GZCO, JAWA, dan PALM.

c. Penyajian aset biologis tanaman tahunan perkebunan tersaji pada laporan posisi keuangan kelompok aset tidak lancar dan mengungkapkan informasi mengenai aset biologis meliputi jumlah tercatata bruti, metode penyusutan, umur atau tarif penyusutan, jumlah rekonsiliasi, jumlah yang digunaan untuk jaminan. Apabila perusahaan menggunakan model revaluasi diungkapkan tanggal efektif revaluasian, adanya penilai independen, dan jumlah selisih.

Perlakuan akuntansi aset biologis sesuai dengan PSAK No 14 tentang persediaan karena:

a. Aset yang diakui sebagai persediaan memenuhi kriteria sebagai persediaan yaitu sebagai barang yang digunakan sebagai proses produksi atau sebagai barang jadi yang siap dijual.

b. Pengukuran persediaan atas aktivitas agrikultural berdasarkan nilai terendeah dari harga perolehan dengan nilai realisasi bersih. Kecuali untuk persediaan tebu diukur berdasarkan harga perolehan.

c. Penyajian persediaan pada kelompok aset lancar dalam laporan posisi keuangan dan mengungkapkan kebijakan akuntansi yang digunakan, jumlah tercatat, jumlah tercatat yang menjadi beban periode berjalan, penurunan nilai, pemulihan nilai, akibat pemulihan nilai, dan nilai persediaan yang menjadi jaminan.

Keterbatasan pada penelitian ini adalah data yang digunakan pada penelitian ini masih menggunakan data sekunder yaitu berupa laporan tahunan yang dipublikasikan oleh perusahaan tanpa melakukan studi kasus langsung seperti wawancara dan observasi ke objek penelitian. Penelitian selanjutnya diharapkan dapat melakukan studi kasus langsung ke objek penelitian dalam menganalisis perlakuan akuntansi atas aset biologis untuk hasil yang lebih baik, menganalisis perlakuan aset biologis berupa hewan, dan dapat menjadi referensi bagi perusahaan untuk lebih detail dalam mengidentifikasi aset biologis yang dimiliki sehingga dapat diketahui perlakuan akuntansi yang bagaimana yang sesuai dengan aset biologis yang dimiliki.

\section{DAFTAR PUSTAKA}

Adita dan Kiswara. (2012). Analisis penerapan International Accounting Standard (IAS) 41. Diponegoro Journal of Accounting, Vol. 1 No.2.

Badan Pusat Statistik. (2016). Produksi perkebunan besar menurut jenis tanaman Indonesia. 12 November 2017. www.bps.go.id.

Badan Pusat Statistik. (2016). Luas tanaman perkebunan besar menurut jenis tanaman Indonesia. $\quad 12 \quad$ November 2017. www.bps.go.id.

Badan Pusat Statistik. (2016). Jumlah perusahaan perkebunan besar menurut jenis tanaman Indonesia. $12 \quad$ November 2017. www.bps.go.id. 
Baridwan, Z. 2010. Intermediate accounting (Edisi Ke-8). Yogyakarta :BPFE.

Cahyani, R. C. dan Aprilina, V. (2014). Evaluasi penerapan SAK ETAP dalam pelaporan aset biologis pada peternakan Unggul Farm Bogor. JRAK, Vol. 5 No. 1.

Eltanto, D. P. (2014). Perlakuan akuntansi dan pph atas industri agrikultur. Tax \& Accounting Review, Vol. 4 No. 1.

Farida, I. (2014). Analisis perlakuan akuntansi aset biologis berdasarkan International Accounting Standard 41 pada PT. Perkebunan Nusantara VII (Persero).

Fauzi, Y. (2017) . Menakar tiga sektor industri 'jagoan'Jokowi. 8 November 2017. www.cnnindonesia.com.

Feleaga, L., dkk. (2012). Theoretical Considerations about Implementation of IAS 41 in Romania. Theoretical and Applied Economics, Vol. XIX No. 2.

Harahap, S.S. 2011. Teori akuntansi (Edisi revisi). Jakarta: Rajawali Pers.

Harnanto. 2007. Akuntansi keuangan menengah. Yogyakarta: BPFE.

Ikatan Akuntan Indonesia. 2015. ED PSAK 69 agrikultur. Dewan Standar Akuntansi Keuangan.

Ikatan Akuntan Indonesia. 2015. PSAK 14 persediaan. Dewan Standar Akuntansi Keuangan.

Ikatan Akuntan Indonesia. 2015. PSAK 16 aset tetap. Dewan Standar Akuntansi Keuangan.

Juan, N.E. dan Ersa T.W. 2013. Panduan praktis standar akuntansi keuangan (edisi ke-2). Jakarta : Salemba Empat.

Korompis, C.W.M.. 2016. Analisis perlakuan akuntansi agrikultur pada petani kelapa pada desa di daerah Likupang Selatan : dampak rencana penerapan ED PSAK NO. 69 Tentang Agrikultur.
Maruli, S. dan Farahmita A. (2011). The analysis of application of fair value and historical cost approaches in the valuation of biological assets in the agricultural companies. Asia pasific Journal of Accounting and Finance, Vol. 1, No. 2.

Moleong, L.J. 2007. Metodologi penelitian kualitatif (edisi revisi). Bandung: PT Remaja Rosdakarya.

Muhammad, A.J. 2009. Tafsir ath-thabari diterjemahkan oleh Amir Hamzah. Jakarta: Pustaka Azzam.

Muhammad, K. dan Erlane K.G. (2014). A fair value model for bearer biological assets in promoting corporate governance. Journal of Agricultural Studies, Vol.2 No. 1.

Murtianingsih dan Anas H.S. (2016). The implementation of fair value on short term assesment of biological assets. Journal of Accounting and Business Education, Vol. 1 No.1.

Putri, D.G.S. (2012). Analisis akuntansi atas biological asset perusahaan perkebunan tanaman keras di PT ASG sebagai studi kasus. Skripsi, Jurusan Ekstensi Fakultas Ekonomi Universitas Indonesia.

Riahi, A. dan Belkaoui. 2006. Teori akuntansi (edisi Ke-5). Jakarta: Salemba Empat.

Sari, A.Y. (2014). Analisis pengakuan, pengukuran, pengungkapan, dan penyajian aset biologis berdasarkan Standar Akuntansi Keuangan pada PT. Perkebunan Nusantara IX (Persero).

Simanjorang, R.D. dan Supatmi. (2014). Praktik perlakuan akuntansi aset biologis pada perusahaan perkebunan (Persero) di Indonesia.

Suwardjono. 2014. Teori akuntansi : perekayasaan pelaporan keuangan (edisi $\mathrm{Ke}-3$ ). Yogyakarta: BPFE. 
Syakur, A.S. 2015. Intermediate accounting (edisi revisi). Jakarta: AV Publisher.

Trina, Z.I. (2017). Analisis perlakuan akuntansi dan deplesi aset biologis berdasarkan IAS 41 pada perusahaan peternakan : studi kasus pada CV. Milkindo Berka Abadi Kapanjen. Skripsi, Jurusan Akuntansi Fakultas Ekonomi Universitas Islam Negeri (UIN) Maulana Malik Ibrahim Malang, Malang

Utomo, R. dan Khumaidah, N.L. (2014). Perlakuan akuntansi aset biologis (tanaman kopi) pada PT. Wahana Graha Makmur - Surabaya. Gema Ekonomi Jurnal Fakultas Ekonomi, Vol. 3, No. 1.

Yani, dkk. (2017). Penyusunan laporan keuangan berdasarkan standar akuntansi keuangan entitas tanpa akuntabilitas publik dengan memperhatikan perlakuan akuntansi aset biologis dan penilaian kinerja pada UD. Rimba Alam. E-Journal S1 Ak Universitas Pendidikan Ganesha, Vol. 7 No. 1. 